\title{
Tutkimuksen asialla
}

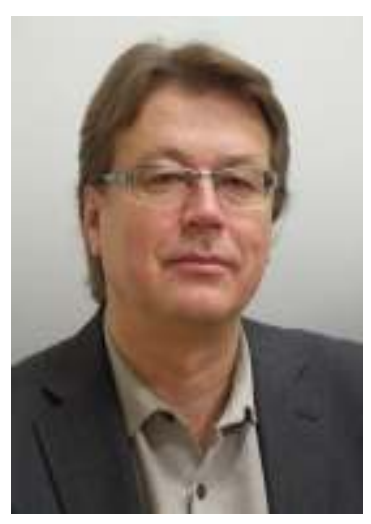

A

ikuiskasvatus juhlistaa tällä numerolla Aikuiskasvatuksen tutkimusseuran 70-vuotista taivalta alan tutkijoiden yhteen kokoajana ja tutkimustoiminnan edistäjänä. Kuten Rainer Aaltonen omassa kirjoituksessaan tässä lehdessä muistuttaa, vuonna 1940 Kansansivistysopillisena Yhdistyksenä aloittanut seura piti tärkeimpänä tehtävänään edistää kansansivistysopillista tutkimusta ja teoreettista keskustelua. Tänään ATS kehittää alan tieteellistä tutkimusta ja tutkijoiden verkostoa niin kansallisesti kuin kansainvälisesti sekä toimii julkaisukanavana alan tutkimukselle. ATS osallistuu tutkimuspoliittiseen keskusteluun pyrkien myös vaikuttamaan aikuiskasvatusta koskevaan tiede- ja koulutuspolitiikkaan. Yhteistyössä Kansanvalistusseuran kanssa Aikuiskasvatuksen Tutkimusseura julkaisee paitsi kädessäsi olevaa Aikuiskasvatus-lehteä myös Aikuiskasvatuksen vuosikirjaa ja Lifelong Learning in Europe-lehteä.

Esihenkilönsä Anja Heikkisen johdolla tutkimusseura on ottanut kunnioitettavaksi tehtäväkseen kehittää tutkimuksen, koulutuksen järjestäjien, kentän ammattilaisten ja hallinnon ja politiikan toimijoiden yhteyksiä ja yhteistyötä. AITURI-hankkeeksi organisoituneen toiminnan lähtökohtana on havainto, että aikuisten kasvua ja oppimista sääteleviä ratkaisuja tehdään kansantaloudellisin, liiketaloudellisin ja työvoimapoliittisin perustein sekä koulutuksen järjestäjien ja työmarkkinaosapuolten intressien ehdoilla ilman, että päätösten perustana olisi tieteellinen tutkimus. Yhteiskunnallinen relevanssi edellyttää tutkimukselta uskottavuutta ja painavaa sanottavaa.

A ikuiskasvatuksen monimuotoinen tutkimuskohde puolestaan edellyttää monitieteistä lähestymistapaa. Yhteiskunnallista todellisuutta tavoitteleva tutkimus ei voi rakentaa vain oppimispsykologian, tapaustarinoiden tai hyvää tarkoittavan sivistystahdon varaan. Tätä nykyä aikuiskasvatus on tutkimuskenttänä fragmentoitunut. Kokonaisuus on kateissa. Kuten Risto Rinne tuonnempana lehdessä arvioi, aikuiskasvatus/aikuiskoulutus potee eräänlaista teoreettista anemiaa. Ilmiön asemointi ja ymmärtäminen suorastaan huutaa teoreettista kehystä ympärilleen. Vaikka "kaiken teorian" tavoittelusta onkin yhteiskuntatieteissä luovuttu, aikuiskoulutus ja elinikäinen oppiminen pitäisi jäsentää yhteydessä yhteiskunnalliseen järjestykseen ja hallintaan, luokkarakenteeseen sekä hyvinvoinnin, resurssien ja vallan jakautumiseen.

Mitä se oikeastaan tarkoittaa, että vuosittain noin 1,7 miljoonaa aikuista osallistuu Suomessa koulutukseen? Kysymys on näin pienessä maassa valtavasta joukosta ihmisiä. Koko Euroopassa ehkä noin 200 miljoonaa aikuista osallistuu koulutukseen vuosittain. Aikuiskoulutus liikuttelee massoja, ja elinikäisen oppimisen välttämättömyyttä korostavan diskurssin kautta se koskettaa jokaista työikäistä. Mitä ovat aikuiskoulutuksen vaikutukset ja kouluttautumisesta koituvat hyödyt ja millaisessa yhteydessä ne ovat kansalaisen luok- 
ka-asemaan (jos tuollaista poliittisesti epäkorrektia ja nykyiseen puhetapaan sopimatonta käsitettä rohkenee käyttää)? Liekö seurausta kasvaneista tuloeroista, kilpailuun ja eriyttämiseen kannustavasta koulutuspolitiikasta vai mistä, mutta luokkanäkökulma on viime vuosina nähty relevanttina tapana lähestyä yhteiskunnallista todellisuutta. Muutokset tulonsiirroissa sekä varallisuuden ja tulonjaossa vaikuttavat suoraan kansalaisten elämänmahdollisuuksiin.

L

ähiaikoina on toteutetaan parikin aikuiskasvatuksen kannalta merkittävää laajamittaista tiedonkeruuta: kansainvälinen aikuistutkimus PIAAC (Programme for the International Assessment of Adult Competencies) ja eurooppalainen aikuiskoulutustutkimus (Suomessa AKU).

PIAAC-tutkimukseen osallistuu 27 maata, ja sillä kerätään tietoa osaamisesta, jota aikuiset käyttävät työelämässä ja arkipäivän toimissaan. Hanketta johtaa Educational Testing Service Yhdysvalloista ja kansainväliseen tutkimusorganisaatioon kuuluu lisäksi kahdeksan muuta tutkimuslaitosta. Suomessa tiedonkeruun suorittaa Tilastokeskus kotikäyntihaastatteluina, ja tutkimuksen toteuttaa ja raportoi Jyväskylän yliopiston Koulutuksen tutkimuslaitos.

PIAAC:in kohdejoukkona on 16-65-vuotias aikuisväestö. Tiedonkeruu tehdään haastatteluina syksyn 2011 ja alkuvuoden 2012 aikana. Otokseen kuuluu 8000 suomalaista. Tutkimuksessa mitataan aikuisten lukutaitoa (kirjoitettujen tekstien ymmärtämistä, arviointia ja käyttöä sekä lukemiseen sitoutumista), numeerisia taitoja (taitoa etsiä, käyttää, tulkita ja viestiä matemaattista informaatiota), ongelmanratkaisutaitoja tietoteknisessä ympäristössä (taitoa hankkia ja arvioida tietoa sekä kommunikoida ja suorittaa käytännöllisiä tehtäviä tietokoneiden ja tietoverkkojen avulla), ja työssä tarvittavia taitoja (kognitiiviset, fyysiset, vuorovaikutus-, sosiaaliset, oppimistaidot). Tutkimus mahdollistaa kansainvälisen vertailun lisäksi ajallisen muutoksen tutkimisen, kun tuloksia verrataan aikaisempiin tutkimuksiin (SIALS, ALL, PISA).

Syksyllä 2012 Tilastokeskus toteuttaa järjestyksessä kuudennen valtakunnallisen aikuiskoulutushaastattelun. Tämä AKU-tutkimus toteutetaan nyt toista kertaa osana eurooppalaista aikuiskoulutustutkimusta 29 EU- ja EFTA-maassa, nyt säädöspohjaisena. Kaikille yhteisenä perusjoukkona ovat 25-64-vuotiaat, maakohtaisesti vapaavalintaisena 18-24- ja 65-69-vuotiaat. Isojen maiden tavoitteena on saada kaikille yhteisestä, "pakollisesta" perusjoukosta 5000 haastattelua ja pienempien maiden (kuten Suomen) 3500 haastattelua. Suurin osa haastattelun kysymyksistä kysytään samanlaisina kaikissa maissa. Suomessa toteutetaan samalla myös kansallinen osa.

Luvassa on erittäin mielenkiintoista tietoa sisältäviä aineistoja, joiden analysointiin tarvitaan myös teoreettista mielikuvitusta.

oimituskunnan puolesta parhaimmat onnittelut 70-vuotiaalle tutkimusseuralle! 